\title{
HYDATID DISEASE OF LIVER- AN OBSERVATIONAL STUDY IN TERTIARY CARE CENTER IN CENTRAL INDIA
}

\author{
Siddharth Shinde ${ }^{1}$, Anurag Jain², Rajiv Jain ${ }^{3}$, Akhilesh Patel ${ }^{4}$
}

${ }_{1}^{1}$ Resident, Department of Surgery, Sri Aurobindo Medical College and PG Institute, Indore, Madhya Pradesh, India.

${ }^{2}$ Assistant Professor, Department of Surgery, Government Medical College, Ratlam, Madhya Pradesh, India.

3 Professor, Department of Surgery, Sri Aurobindo Medical College and PG Institute, Indore, Madhya Pradesh, India.

${ }^{4}$ Resident, Department of Surgery, Sri Aurobindo Medical College and PG Institute, Indore, Madhya Pradesh, India.

\section{ABSTRACT}

\section{BACKGROUND}

Hydatid cyst is caused by the tapeworm Echinococcus granulosus. The abdomen, specifically the liver, is the most commonly affected organ. This study was carried out to determine the presentation patterns, types of surgical management, and outcomes of patients operated for intra-abdominal liver hydatid cyst (IAHC).

\section{METHODS}

We performed a combined prospective \& retrospective observational study, in the department of surgery in a tertiary care centre, Sri Aurobindo Medical College \& P.G. Institute, Indore (M.P.). We included patients of age ranging between 18 to 60 years for prospective study from December 2016 to June 2018 \& for retrospective study from June 2015 to December 2016.

\section{RESULTS}

Total 41 patients were included in our study. The distribution of disease between male and female was $70.7 \%$ and $29.3 \%$ respectively. The right lobe harboured the cyst in $61.0 \%$ cases and the left in $34.1 \%$ \& $4.9 \%$ of the patients had disease in both the lobes. In the present study, the commonest symptom of hydatid cyst of liver was mass per abdomen in 21 patients (51.2\%) followed by pain in abdomen in 20 patients (48.8\%) and nausea in 34.1\%. In our study, 22 (53.7\%) patients underwent laparoscopic surgery, 13 (31.7\%) patients underwent open surgery, 1 (2.4\%) patient underwent PAIR and 5 (12.2\%) patients received expectant treatment.

\section{CONCLUSIONS}

Most common location of liver hydatid was found to be right lobe. Majority of liver hydatid were treated by laparoscopic surgery in which deroofing with omentoplasty was done, which was found to be an optimum treatment in our institute.

\section{KEY WORDS}

Echinococcosis, Hepatic Hydatid Disease, Scolicidal Agent, Laparoscopic, Omentoplasty, Marsupialization, Cystopericystectomy, Enucleation, External Drainage, Capitonnage, Enucleation, Pair

HOW TO CITE THIS ARTICLE: Shinde S, Jain A, Jain R, et al. Hydatid disease of liver- an observational study in tertiary care center in Central India. J. Evolution Med. Dent. Sci. 2019;8(22):1767-1771, DOI: 10.14260/jemds/2019/388

\section{BACKGROUND}

Hydatid disease is a well-known disease since ages. It was known to Hippocrates, who described it as "liver full of water". Hydatid disease more prevalent in Australia, New Zealand, South America, Russia, France, China, India, and the Middle East countries.(1,2)Echinococcosis (Hydatid disease) is a zoonosis caused by the larval stage of Echinococcus granulosus. Humans are accidental intermediate hosts, whereas animals can be both intermediate hosts and definitive hosts. The two main types of hydatid disease are caused by E. granulosus and E. multilocularis. The name of hydatid cyst was first used by Rudolphi and derived from Greek word "hydatid" meaning a drop of water. Sometimes inside the cysts, laminated membrane appear granular, hence

'Financial or Other Competing Interest': None.

Submission 14-04-2019, Peer Review 18-05-2019,

Acceptance 24-05-2019, Published 03-06-2019.

Corresponding Author:

Dr. Anurag Jain,

\#27, Anand Bagichi,

Agrawal Nagar,

Indore, Madhya Pradesh,

India.

E-mail: rajivrameshjain@gmail.com

DOI: $10.14260 /$ jemds/2019/388 the term granulosus. No organ in the body is immune to this disease. The disease occurs in the liver in $70 \%$ of cases, the lungs in $25 \%$ of cases and at other sites such as the spleen, kidney, pancreas, brain, ovary, mesentery, vertebra and soft tissue of the neck. Anaphylactic shock, cyst infection of the biliary tree and rupture into the peritoneum are the most severe complications.(3) Exposure of man at common place and the organism is endowed with many adaptive mechanisms for survival and perpetuation of the species. It has slow pace of growth in man but in the end either the parasite or the host must die. Humans are an end stage to the parasite, and it can occur in any age group. Early diagnosis is required to reduce the morbidity and mortality. Diagnosis is possible by serological and radiological investigations even at an early stage of disease. The treatment options for the disease vary from medical line of management to various surgical procedures which stand as challenge to surgeons and sometimes complicated by life threatening outcomes. This study included 41 patients with hydatid disease of liver from December 2016 to June 2018.

Aim of The Study

To study the clinical profile of hydatid disease of liver. 


\section{Objectives of The Study}

- To study the various clinical presentations of hydatid disease of liver.

- To study the different diagnostic modalities of hydatid disease of liver.

- To study the outcome of conservative management and surgical intervention in hydatid disease of liver.

\section{METHODS}

This observational study was performed in a prospective as well as retrospective manner in surgery department of Sri Aurobindo medical college \& P.G Institute, Indore (M. P). All the patients admitted in surgery wards with hydatid disease of liver between the age group of 18 to 60 years were selected for prospective study from December 2016 to June 2018 (Duration 1 year \& 6 months). For Retrospective study, the relevant data about the patients of Hydatid Disease of Liver were collected from Medical Records Department from June 2015 to December 2016(duration 1 year \& 6 months). The following criteria were used for selection of patients. All the 41 patients those were included in this study after taking written informed consent.

\section{Inclusion Criteria}

- All patients presenting with hydatid disease of Liver above 18 years.

- All patients who are willing for the study.

- $\quad$ Patients with hydatid disease of liver (only liver).

These selected cases were noted down in the structured Proforma specially designed for this study with details of their demography, clinical features, radiological investigation used for diagnosis (USG, CT scan, both), line of management (Medical or surgical), type of surgical intervention performed (open surgery or laparoscopic surgery) and post- operative complications.

After data collection, the results thus obtained were tabulated \& relevant statistical analysis was done and outcome of the various parameters was studied.

\section{RESULTS}

Our study on "Clinical profile of Hydatid Cyst of Liver" done in Surgery department of Sri Aurobindo Medical College and P.G. institute constituted of 41 patients out of which 21 patients were added prospectively while 20 patients were retrospectively collected from the Medical records department of our institute.

\begin{tabular}{|c|c|c|}
\hline Age Group & Number & Percentage \\
\hline 19-20 years & 1 & 2.4 \\
\hline 21-30 years & 10 & 24.4 \\
\hline 31-40 years & 10 & 24.4 \\
\hline 41-50 years & 11 & 26.8 \\
\hline 51-60 years & 9 & 22.0 \\
\hline Total & $\mathbf{4 1}$ & $\mathbf{1 0 0 . 0}$ \\
\hline
\end{tabular}

Table 1. Distribution of Patients According to Age

The above table shows the distribution of patients according to age. Majority of the patients were in the age group $41-50$ years $(26.8 \%)$.

\begin{tabular}{|c|c|c|}
\hline Sex & Number & Percentage \\
\hline Male & 29 & 70.7 \\
\hline Female & 12 & 29.3 \\
\hline Total & $\mathbf{4 1}$ & $\mathbf{1 0 0 . 0}$ \\
\hline Table 2. Distribution of Patients According to Sex \\
\hline $\begin{array}{c}\text { The above table shows the distribution of patients according to sex. } \\
\text { There were 29 (70.7\%) males in our study, showing a male } \\
\text { preponderance. }\end{array}$ \\
\hline
\end{tabular}

\begin{tabular}{|c|c|c|}
\hline Occupation & Number & Percentage \\
\hline Famers & 15 & 36.6 \\
\hline Housewife & 10 & 24.4 \\
\hline Self-business & 7 & 17.1 \\
\hline Student & 5 & 12.2 \\
\hline Government Employee & 2 & 4.9 \\
\hline Private Employee & 2 & 4.9 \\
\hline Total & 41 & 100.0 \\
\hline
\end{tabular}

The above table shows the distribution of patients according to occupation. Majority of our patients were farmers, 15 (36.6\%) followed by housewives.

\begin{tabular}{|c|c|c|}
\hline H/o Contact with Animals & Number & Percentage \\
\hline Yes & 29 & 70.7 \\
\hline No & 12 & 29.3 \\
\hline Total & $\mathbf{4 1}$ & $\mathbf{1 0 0 . 0}$ \\
\hline \multicolumn{2}{|c|}{ Table 4. Distribution of Patients According to } \\
History of Contact with Animals \\
\hline The above table shows the distribution of patients according to \\
history of contact with animals. 29 (70.7\%) patients had significant \\
history of contact with animals.
\end{tabular}

\begin{tabular}{|c|c|c|}
\hline Presenting Complaints & Number & Percentage \\
\hline Abdominal mass & 21 & 51.2 \\
\hline Abdominal pain & 20 & 48.8 \\
\hline Nausea & 14 & 34.1 \\
\hline Dyspepsia & 10 & 24.4 \\
\hline Fever & 8 & 19.5 \\
\hline Pruritus & 6 & 14.6 \\
\hline Jaundice & 2 & 4.9 \\
\hline Cough & 1 & 2.4 \\
\hline \multicolumn{3}{|c|}{$\begin{array}{l}\text { Table 5. Distribution of Patients According to } \\
\text { Presenting Complaints }\end{array}$} \\
\hline \multicolumn{3}{|c|}{$\begin{array}{l}21(51.2 \%) \text { patients presented with complaints of abdominal mass, } \\
\text { In majority of the patients } 21(51.2 \%) \text { presented with complaints of } \\
\text { abdominal mass, followed by abdominal pain, nausea, dyspnoea as } \\
\text { most common presenting complaints. }\end{array}$} \\
\hline
\end{tabular}

\begin{tabular}{|c|c|c|}
\hline Location & Number & Percentage \\
\hline Right lobe & 25 & 61.0 \\
\hline Left lobe & 14 & 34.1 \\
\hline Both lobes & 2 & 4.9 \\
\hline Total & $\mathbf{4 1}$ & $\mathbf{1 0 0 . 0}$ \\
\hline Table 6. Distribution of Patients According to \\
Location of Hydatid Cyst \\
\hline $\begin{array}{c}\text { In majority of the patients 25 (61.0\%), location of hydatid cyst was } \\
\text { Right lobe. }\end{array}$
\end{tabular}

\begin{tabular}{|c|c|c|}
\hline & & $(\mathrm{N}=36)$ \\
\hline Type of Surgery & Number & Percentage \\
\hline Deroofing with omentoplasty & 9 & 25.0 \\
\hline Marsupialization & 6 & 16.7 \\
\hline Marsupialization with omentoplasty & 5 & 13.9 \\
\hline Cystopericystectomy & 5 & 13.9 \\
\hline Cystopericystectomy with omentoplasty & 4 & 11.1 \\
\hline Enucleation with external drainage & 3 & 8.3 \\
\hline Capitonnage & 2 & 5.6 \\
\hline Enucleation with capitonnage & 1 & 2.8 \\
\hline Pair & 1 & 2.8 \\
\hline Total & 36 & 100.0 \\
\hline \multicolumn{3}{|c|}{ Table 7. Distribution of Patients According to Type of Surgery } \\
\hline \multicolumn{3}{|c|}{$\begin{array}{l}\text { Majority of the patients underwent laparoscopic deroofing with } \\
\text { omentoplasty and marsupialization. }\end{array}$} \\
\hline
\end{tabular}




\begin{tabular}{|c|c|c|}
\hline & & $(\mathrm{N}=36)$ \\
\hline Postoperative complications & Number & Percentage \\
\hline Fever & 5 & 13.8 \\
\hline Biliary fistula & 4 & 11.1 \\
\hline Fever with wound infection & 2 & 5.5 \\
\hline Basal atelectasis with wound infection & 1 & 2.7 \\
\hline Pneumonitis with fever & 1 & 2.7 \\
\hline Port site infection & 1 & 2.7 \\
\hline Total & 14 & $38.8 \%$ \\
\hline \multicolumn{3}{|c|}{$\begin{array}{l}\text { Table 8. Distribution of Patients According to } \\
\text { Postoperative Complications } \\
\end{array}$} \\
\hline \multicolumn{3}{|c|}{$\begin{array}{l}\text { Out of } 36 \text { patients, } 14 \text { (38.8\%) had postoperative complications in } \\
\text { which most common was fever } 5 \text { (13.8\%) followed by biliary fistula, } \\
\text { respiratory \& port site infection. }\end{array}$} \\
\hline
\end{tabular}

\begin{tabular}{|c|c|c|}
\hline Outcome & Number & Percentage \\
\hline Discharged satisfactorily & 25 & 60.9 \\
\hline Discharged after ERCP stenting & 4 & 9.8 \\
\hline Needed surgery in long-term follow-up & 5 & 12.2 \\
\hline Discharged after prolonged wound & 3 & 7.3 \\
\hline Management & & \\
\hline Recurrence & 4 & 9.8 \\
\hline Total & $\mathbf{4 1}$ & $\mathbf{1 0 0 . 0}$ \\
\hline \multicolumn{2}{|c|}{ Table 9. Distribution of Patients According to Outcome } \\
\hline $\begin{array}{c}\text { Majority of the patients were discharged satisfactorily. Recurrence } \\
\text { rate was low (9.8\%) }\end{array}$ \\
\hline
\end{tabular}

\begin{tabular}{|c|c|c|}
\hline Duration of Hospital Stay & Number & Percentage \\
\hline$<=3$ days & 5 & 12.2 \\
\hline $3-7$ days & 17 & 41.5 \\
\hline $7-14$ days & 14 & 34.1 \\
\hline$>14$ days & 5 & 12.2 \\
\hline Total & $\mathbf{4 1}$ & $\mathbf{1 0 0 . 0}$ \\
\hline Table 10. Distribution of Patients According to \\
Duration of Hospital Stay \\
\hline
\end{tabular}

17 (41.5\%) had a hospital stay of 3-7 days \& Majority of the patients had hospital stay of less than 7 days. The mean hospital stay was $8.42 \pm 4.66$ days.

\begin{tabular}{|c|c|c|}
\hline & Present Study (\%) & R.B. Mehta et al \\
\hline Age in Year & $(\mathbf{n}=\mathbf{4 1})$ & $(\mathbf{n}=\mathbf{4 8})^{4}$ \\
\hline $21-30$ & 24.4 & 27.1 \\
\hline $31-40$ & 24.4 & 18.8 \\
\hline $41-50$ & 26.8 & 18.8 \\
\hline $51-60$ & 22.0 & 6.3 \\
\hline$>60$ & - & 4.2 \\
\hline \multicolumn{3}{|c|}{ Table 11. Age Incidence in Various Studies } \\
\hline
\end{tabular}

\begin{tabular}{|c|l|c|l|c|}
\hline & $\begin{array}{c}\text { Present } \\
\text { study }\end{array}$ & R.B. Mehta & Ahmed A. & Palanivelu \\
\hline & $(\%)$ & et al $^{4}$ & et al $^{6}$ & et al $^{5}$ \\
\hline & $(\mathrm{n}=41)$ & $(\mathrm{n}=48)$ & $(\mathrm{n}=304)$ & $(\mathrm{n}=66)$ \\
\hline Male & 70.7 & 56.3 & 34.5 & 83.3 \\
\hline Female & 29.3 & 43.7 & 65.5 & 16.7 \\
\hline \multicolumn{5}{|c|}{ Table 12. Sex Incidence in Various Studies } \\
\hline
\end{tabular}

\begin{tabular}{|c|c|c|c|}
\hline \multirow{2}{*}{} & Present Study & R. N. Sibal ${ }^{7}$ & S. K. \\
\cline { 2 - 4 } & $(\mathbf{n}=41)$ & & Bhobhate $^{\mathbf{8}}$ \\
\hline & & $(\mathrm{n}=79)$ \\
\hline Present & 70.7 & 32.6 & 49.4 \\
\hline Absent & 29.3 & 67.4 & 50.6 \\
\hline Table 13. History of Contact with Animals in Various Studies \\
\hline
\end{tabular}

\begin{tabular}{|c|c|c|c|c|}
\hline Symptoms & $\begin{array}{c}\text { Present } \\
\text { Study } \\
\text { (n=41) }\end{array}$ & $\begin{array}{c}\text { R. V. S. } \\
\text { Yadav } \\
\text { et al.10 } \\
\text { (n=70) }\end{array}$ & $\begin{array}{c}\text { Ahmed A. } \\
\text { et al }^{\mathbf{6}} \\
\mathbf{( n = 3 0 4 )}\end{array}$ & $\begin{array}{c}\text { Palanivelu }_{\text {et al }}^{\mathbf{5}} \\
\mathbf{( n = 6 6 )}^{\mathbf{n}=\mathbf{6 0 6}}\end{array}$ \\
\hline Mass & 51.2 & 85.7 & 55 & 19.7 \\
\hline Pain & 48.8 & 61.4 & 74 & 51.5 \\
\hline Nausea & 34.1 & - & - & 22.7 \\
\hline Dyspepsia & 24.4 & - & - & \\
\hline Fever & 19.5 & 35.7 & 22.7 & 1.5 \\
\hline Pruritus & 14.6 & - & - & - \\
\hline Jaundice & 4.9 & 12.8 & 5.9 & - \\
\hline
\end{tabular}

\begin{tabular}{|c|c|c|c|c|}
\hline $\begin{array}{c}\text { Acute } \\
\text { abdomen }\end{array}$ & - & - & 1 & \\
\hline Asymptomatic & - & - & 9.5 & 4.6 \\
\hline \multicolumn{6}{|c|}{ Table 14. Common Symptoms of Liver Hydatid Disease in } \\
Various Studies \\
\hline
\end{tabular}

\begin{tabular}{|c|c|c|c|c|}
\hline Location & $\begin{array}{c}\text { Present } \\
\text { Study } \\
(\%)(n=41)\end{array}$ & $\begin{array}{l}\text { R. V. S. Yadav } \\
\text { et al } \mathbf{l}^{10}(n=60)\end{array}$ & $\begin{array}{c}\text { Ahmed A. } \\
\text { et } \text { al }^{6}(n=304)\end{array}$ & $\begin{array}{c}\text { Palanivelu } \\
\text { et al }{ }^{5} \\
(\mathrm{n}=66)\end{array}$ \\
\hline Right lobe & 61.0 & 65 & 78.3 & 54.5 \\
\hline Left lobe & & & & 39.4 \\
\hline Both lobes & 4.9 & 11.7 & 8.2 & 6.1 \\
\hline
\end{tabular}

\begin{tabular}{|c|c|c|}
\hline Type of Treatment & Present Study (n=41) & $\begin{array}{c}\text { Yagci G et al11 } \\
(\mathbf{n}=\mathbf{3 5 5})\end{array}$ \\
\hline Laparoscopic & 53.7 & 8.4 \\
\hline Open & 31.7 & 52.0 \\
\hline PAIR & 2.4 & 36.6 \\
\hline Expectant & 12.2 & - \\
\hline \multicolumn{2}{|c|}{ Table 16. Type of Treatment Received by } \\
Patients in Various Studies
\end{tabular}

\begin{tabular}{|c|c|c|c|}
\hline Type of Surgery & $\begin{array}{c}\text { Present } \\
\text { Study (\%) } \\
(\mathbf{n = 4 1 )}\end{array}$ & $\begin{array}{c}\text { Ahmed A } \\
\text { et al }^{\mathbf{6}} \\
(\mathbf{n = 3 0 4 )}\end{array}$ & $\begin{array}{c}\text { R. V. S. } \\
\text { Yadav et al } \\
\left(\mathbf{n = 6 0 )} \mathbf{1 0}^{\mathbf{1 0}}\right.\end{array}$ \\
\hline Marsupialization & 26.8 & 28.6 & - \\
\hline a)Without omentoplasty & 14.6 & & \\
\hline b)With omentoplasty & 12.2 & & - \\
\hline Deroofing with omentoplasty & 22.0 & - & - \\
\hline Cystopericystectomy & 22.0 & - & - \\
\hline a)Without omentoplasty & 12.2 & & \\
\hline b)With omentoplasty & 9.8 & & \\
\hline Omentoplasty & 43.9 & 13.2 & 1.7 \\
\hline Enucleation with & 7.3 & 43.4 & 56.7 \\
\hline a)External drainage & 4.9 & 40.1 & 36.7 \\
\hline b)Capitonnage & 2.4 & 3.3 & 20.0 \\
\hline Only Capitonnage & 4.8 & 32.9 & 6.6 \\
\hline Pair & 2.4 & 33.2 & - \\
\hline Table 17. Treatment of Liver Hydatid Cyst \\
According to Type of Surgery in Various Studies \\
\hline \multicolumn{4}{|l}{} \\
\hline
\end{tabular}

\begin{tabular}{|c|c|c|c|}
\hline Postoperative Complication & $\begin{array}{c}\text { Present } \\
\text { Study } \\
(\mathbf{n = 4 1 )}\end{array}$ & $\begin{array}{c}\text { Ahmed A } \\
\text { et al. } \\
(\mathbf{n = 3 0 4}\end{array}$ & $\begin{array}{c}\text { Palanivelu } \\
\text { et al }^{\mathbf{5}} \\
(\mathbf{n = 6 0 )}\end{array}$ \\
\hline $\begin{array}{c}\text { Infection (Fever, port site } \\
\text { infection and wound infection) }\end{array}$ & 24.3 & 47.7 & 3.2 \\
\hline Biliary fistula & 9.7 & 8.2 & 13.6 \\
\hline Pulmonary & & & \\
\hline $\begin{array}{c}\text { Complication (Basal atelectasis } \\
\text { \& pneumonitis) }\end{array}$ & 4.9 & 1.1 & - \\
\hline
\end{tabular}

Table 18. Post-Operative Complications of Liver Hydatid in Various Studies

\begin{tabular}{|c|c|}
\hline Type of Treatment & Mean \pm SD (Hospital Stay in Days) \\
\hline Tube drainage (Infected) & $27.9 \pm 7.9$ \\
\hline Tube drainage (Uncomplicated) & $16.1 \pm 3.0$ \\
\hline Capitonnage & $11.2 \pm 2.8$ \\
\hline Omentoplasty & $11.2 \pm 2.6$ \\
\hline
\end{tabular}

\section{DISCUSSION}

In our study we had patients of all age groups more than 18 years [as per inclusion criteria]. In our study, the youngest patient was of 19 years and the oldest age being 60 years. The commonest age group was between 41-50 years. We compared our study with the study done by R.B. Mehta et al, which included 48 patients of hydatid disease distributed in various age groups. In their study, they found the commonest age group was between 21-30 years of age (27.1\%). While Palanivelu et $\mathrm{al}^{5}$ in his study found that the youngest patient was of 14 years \& oldest of 64 years \& the mean age of patients was 38.6 years. 
The distribution of disease between male and female was $70.7 \%$ and $29.3 \%$ respectively in our study. In Ahmed A et al, a study of 304 patients there were $34.5 \%$ male \& $65.5 \%$ of female with hydatid disease. In R.B Mehta et al study females accounted for $43.7 \%$ and males constituted $56.3 \%$ and in Palanivelu et al there were $83.3 \%$ males and only $16.7 \%$ were females. Our study and Palanivelu et al study both showed male predominance with disease infestation.

In the present study, history of contact with animals was present in $70 \%$ of patients which is not in concordance with R.N. Sibal et al, study of 43 cases where history of contact with dog or sheep was present in $32.6 \%$ of patients. In S.K. Bhobhate et al study $49.4 \%$ of patients gave history of contact with dog or sheep. Moreover, poor personal hygiene, usage of unwashed vegetables, unwashed hands, and low socioeconomic status adds to the risk. Agriculture was the most common occupation of our patients $(36.6 \%)$ followed by housewife (24.4\%). G.H. Upadhyaya et $\mathrm{al}^{9}$ also reported in their study that most patients with hydatid disease were labourers with a low socioeconomic status. Thus, occupation like agriculture and low socioeconomic status where exposure to animals and poor personal hygiene practice is common.

In the present study, the commonest symptom of hydatid cyst of liver was mass per abdomen in 21 patients $(51.2 \%)$ followed by pain in abdomen in 20 patients (48.8\%) and nausea in $34.1 \%$ \& dyspepsia in $24.4 \%$ while the least common complaint was jaundice present in only $1(4.9 \%)$ patient.In study by Palanivelu et al, majority of the patients (51.5\%) had pain as their presenting complaint followed by Nausea \& dyspepsia in $22.7 \%$. While in the study by R.V.S. Yadav et al., $85.7 \%$ patients had mass and $61.4 \%$ had pain in abdomen which is comparable with our study. Whereas that by Ahmed A. et al study showed pain to be the most common symptom $74 \%$ followed by mass in $53 \%$ cases. The presentation of cases with mass could be due to the fact that most patients neglected their aching pain or took on the counter analgesics and never consulted their doctors due to ignorance or low financial status.

In our study the right lobe harboured the cyst in $61.0 \%$ cases and the left in $34.1 \%$ \& $4.9 \%$ of the patients had disease in both lobes. In the study by Palanivelu et al, $54.5 \%$ patients had cysts in right Lobe and $39.4 \%$ patients had cyst in left lobe while $6.1 \%$ of the patients had cysts in both lobes of liver and in the study done by R.V.S. Yadav et al, $65 \%$ patients had cysts in right lobe and 18\% had in left lobe and that in Ahmed A. et al study $78 \%$ patients had cysts in right lobe and only $13 \%$ of cases in left lobe. Thus, our study is comparable \& comes to a conclusion that the Right lobe of liver is more commonly involved in hydatid disease of liver.

In our study 22 (53.7\%) patients underwent laparoscopic surgery, 13 (31.7\%) patients underwent open surgery, 1 (2.4\%) patient underwent PAIR and 5 (12.2\%) patients received expectant treatment while Yagci et al did a study of 355 patients and managed all of them with a surgical approach, found that of all patients, Open surgery was done in 185 patients (52.0\%), laparoscopic in 30(8.4\%) patients while PAIR was done in 130 (36.6\%) patients.

In our study, 9 (25.0\%) patients underwent laparoscopic deroofing with omentoplasty, $6(16.7 \%)$ patients underwent marsupialization, $5 \quad(13.9 \%)$ patients underwent marsupialization with omentoplasty, 5 (13.9\%) patients underwent cystopericystectomy, 4 (11.1\%) patients underwent cystopericystectomy with omentoplasty, 3 (8.3\%) patients underwent enucleation with external drainage, 2 (5.6\%) patients underwent capitonnage, and $1(2.8 \%)$ patient each underwent enucleation with capitonnage and PAIR. Majority of the patients underwent laparoscopic deroofing with omentoplasty \& marsupialization.

In study by Ahmed A. et al, shows $40.1 \%$ patients underwent external drainage and $13.2 \%$ underwent omentoplasty. The rest of the patients underwent some other procedures, most commonly capitonnage. The study by R.V.S. Yadav et al shows $36.7 \%$ patients underwent external drainage and only $1.7 \%$ patients underwent omentoplasty.

On comparison of our study with the above 2 studies, enucleation with external tube drainage, omentoplasty \& capitonnage was the common procedure adopted to deal with the pathology.

While in the Palanivelu Hydatid System (PHS $)^{5}$ specifically designed to prevent spillage of hydatid fluid for laparoscopic management of hydatid cysts, a specially designed trocar was used to obtain a totally contaminationfree management of liver hydatid disease.

In our study, postoperative complications were seen in total 14 cases (39.9\%) some patients had more than one complication i.e. fever with wound infection etc. All our patients were followed up every month after discharge for a minimum period of 6 months for persistent symptoms and/or other complications of disease or surgery. Various reports in the literature reveal a recurrence rate varying from $0.9 \%$ to $22 \%$ for open surgery. ${ }^{6}$ We also calculated the duration of hospital stay of our patients and found that the mean hospital stay was $8.4+4.6$ days and majority of the patients were discharged within 7 days followed by 7-14 days. In the study done by Ahmed et al7, he found that the average hospital stay was longer in the tube drainage group as compared with the other groups. In Ahmed et al7 study.

\section{CONCLUSION}

Hydatid disease of liver is more commonly seen in middle aged \& elderly age group, males, low socioeconomic status, and in individuals involved in agriculture. There is usually history of contact with animals. Mass per abdomen was the most common presenting feature in liver hydatid. Most common location of liver hydatid was found to be right lobe. Majority of liver hydatids was treated laparoscopically which is an optimum treatment in our institute. Outcome of the patient correlates with the type of treatment received. Infection and biliary fistula were the common complications post operatively in liver hydatid. Recurrence was observed in the follow up of patients during the study period and no mortality was documented. All the patients with complications were managed accordingly \& were discharged satisfactorily. Laparoscopic technique is safe and simple as compared to open abdominal surgery the advantage being prevention of intraperitoneal spillage of cyst contents.

\section{REFERENCES}

[1] Nemati A, Kamagarpour A, Rashid M, et al. Giant cerebral hydatid cyst in a child - a case report and review of literature. Br J Med Pract 2010;3(3):a338. 
[2] Kovoor JM, Thomas RD, Chandrashekhar HS, et al. Neurohydatidosis. Australas Radiol 2007;51(5):40611.

[3] Lewall DB. Hydatid disease: biology, pathology, imaging and classification. Clin Radiol 1998;53(12):863-74.

[4] Mehta RB, Ananthkrishnan N, Gupta BK, et al. Hydatid disease in Pondicherry. Indian J Surg 1982;44:88-94.

[5] Palanivelu C, Jani K, Malladi V, et al. Laparoscopic management of hepatic hydatid disease. JSLS 2006;10(1):56-62.

[6] Balik AA, Basoglu M, Celebi F, et al. Surgical treatment of hydatid disease of the liver: a review of 304 cases. Archives of Surgery 1999;134(2):166-9.
[7] Sibal RN, Singh P. Hydatid disease in Himachal Pradesh. J Ind Med 1974;63(7):211-3.

[8] Bhobhate SK, Kedar GP, Kher AV. Incidence of hydatid disease in Vidharbha division. Indian J Surg 1984;46:162-4.

[9] Upadhyay GH, Rai P, Shah PK. Clinical study of hydatid disease in Jamnagar. J Ind Med 1974;63(7):213-6.

[10] Yadav RVS, Mintz M, Wig JD, et al. Management of hydatid cyst of the Liver. Indian Journal of Surgery 1989;51:187-90.

[11] Yagci G, Ustunsoz B, Kaymakcioglu N, et al. Results of surgical, laparoscopic and percutaneous treatment for hydatid disease of the liver: 10 years of experience with 355 patients. World J Surg 2005;29(12):1670-9. 